\title{
O CONTROLE DE CONSTITUCIONALIDADE: BOSQUEJO DE SUA HISTÓRIA
}

\author{
Acácio Vaz de Lima Filho \\ Doutorando pela Faculdade de Direito da \\ Universidade de São Paulo
}

\begin{abstract}
Resumo:
Neste artigo, buscamos fazer uma brevíssima sintese histórica da evolução do controle de constitucionalidade. Abordamos o assunto no Direito Público de Atenas, na Grécia Antiga, e a sua ulterior evolução, em Roma, na Europa Medieval, e na América do Norte, com a Constituição de 1787. Passando pelo "sistema americano" e pelo "sistema austríaco" chegamos ao Direito brasileiro, sob a Constituição de 1988.
\end{abstract}

\section{Abstract:}

In this article, we looked for to do a short historical synthesis of the evolution of the constitutionality control. We study the subject in the Public Law of Athens, in Old Greece, and its ulterior evolution, in Rome, in Medieval Europe, and in North America, with the Constitution of 1787. Going by the "American System" and the "Austrian System" we arrived to the Brazilian Law, under the Constitution of 1988.

Unitermos: legislação de Atenas; Direito grego; Direito Romano; Direito Natural; "sistema difuso" ou "americano"; "sistema concentrado" ou "austríaco"

Sumário: I - A legislação de Atenas, o mais antigo precedente histórico; II - Roma: o pensamento de Marco Tulio Cícero; III - A Idade Média. Jus Naturale e Jus Positum; IV - O Jusnaturalismo dos séculos XVII e XVIII; V Inglaterra. A luta entre el-Rei e o parlamento. A "Revolução Gloriosa" e a supremacia do parlamento; VI A contribuição norte-americana; VII Direito atual: o sistema "difuso" ou "americano" e o sistema "concentrado" ou "austríaco" do controle judicial da constitucionalidade das leis; VIII O Direito brasileiro sob a égide da Constituição de 1988, XI Conclusões finais; Bibliografia. 
I A legislação de Atenas, o mais antigo precedente histórico

Cremos andar com acerto o insigne professor Miguel Reale, quando afirma que, ao passo que os gregos se destacaram pelo uso especulativo da razão, os romanos se notabilizaram pelo seu uso prático. ${ }^{\prime}$ A propósito deste assunto, já tivemos a oportunidade de escrever, verbis:

"Uma outra caracteristica dos romanos residia em serem, eles, avessos às especulações teoréticas, e voltados para a concreção da existência. Neste sentido, lembramos que, ao passo que o gênio grego encontrou a sua manifestação maior na Filosofia, o gênio romano a encontrou no Direito" ${ }^{2}$

Ao cotejar os helenos e a gente do Lácio, escreveu por sua vez o saudoso professor Gabriel José Rodrigues de Rezende Filho:

"Os gregos, que tão alto elevaram as artes e a filosofia, mostraram-se, todavia, estéreis em assuntos jurídicos.

Roma foi, realmente, o berço do direito" ${ }^{3}$

Pouco adiante, aduzia o ilustre processualista das Arcadas:

Povo guerreiro e prático, o romano, antes de tudo, respeitava profundamente as leis, razão pela qual o seu direito teve rápida e brilhante evolução" ${ }^{4}$

1. Vide Horizontes do Direito e da História, São Paulo, Saraiva S.A. Livreiros Editores, $2^{2}$ ed. revista e aumentada, 1977, p. 55.

2. Vide, de Acacio Vaz de Lima Filho, O Poder na Antiguidade: Aspectos Históricos e Jurídicos, São Paulo, Icone Editora, 1999, p. 146.

3. Vide Curso de Direito Processual Civil, São Paulo, Edição Saraiva, $3^{a}$ ed., 1952, v. I, p. 44. 
Para resumir - e concluir - a Filosofia foi a vocação nacional dos helenos, ao passo que a Jurisprudência foi a vocação nacional dos romanos. Esta assertiva não deve, no entanto, levar o estudioso a pontos de vista extremados, como aquele, aliás, muito difundido, de que os gregos seriam incapazes de ter vida jurídica... ora, esta é uma estultice. Em toda civilização digna deste nome, como o lobrigou Pietro de Francisci, um dos elementos fundamentais é o elemento jurídico. Ocorre que em nenhum outro povo este fator - o jurídico - teve tão grande relevo quanto o que ostentou entre a gente do Lácio. De acordo com o festejado romanista italiano, teria sido este ímpar senso jurídico dos romanos, indissociável dos valores políticos, que teria ensejado o surgimento da noção de Res Publica" 5

$\mathrm{Na}$ abordagem do assunto de que ora nos ocupamos - o controle de constitucionalidade - é preciso que nos debrucemos sobre o Direito grego, e, mais especificamente, sobre a legislação de Atenas, na qual, ao que tudo indica, é possível encontrar o embrião do nosso hodierno controle de constitucionalidade. É o que ora vamos procurar fazer.

Uma consideração introdutória deve aqui ser feita, pertinente à diferença de concepção da "lei", entre os romanos e entre os gregos. Para os primeiros, a "lex" era uma emanação da "voluntas" humana. Para os segundos, ao revés, a "lei" era a emanação do querer divino. A propósito, escrevemos, verbis.

"Por fim, em matéria legislativa, competia à 'Eclésia o poder de estabelecer regras de conduta, vinculantes, expressas na forma da lei, ou do decreto. Elucidam Biscardi e Cantarella que, para os gregos, as leis não eram o produto da vontade da 'Polis', e sujeitas portanto - pela sua própria natureza - a mudanças contínuas. Para os gregos a lei era qualquer coisa de transcendente, de preexistente ao Direito. A 'lei', era o produto do querer da divindade, não passando, o legislador, de intérprete da vontade divina. Os autores, para ilustrar a assertiva, mencionam a legislação de

4. Op., vol. e loc. cit.

5. Vide Sintesis Historica Del Derecho Romano, tradução espanhola Madrid, Editorial Revista de Derecho Privado, 1954, p. 123 - original italiano. 
Esparta, aconselhada a Licurgo pelo oráculo de Delfos" $^{\prime \prime}$

Em continuação, escrevemos:

Aqui nos interessa de peryo o fato de que, revestindo a 'lei' a característica apontada (a de ser a emanação da vontade divina, e não do querer humano), várias conseqüências daí derivavam. Com efeito, emanadas do querer divino, as leis eram, ao menos em princípio, imutáveis, e fácil é inferir que a proposição de novas leis era algo excepcional. $O$ que garantia tal excepcionalidade, é que havia uma série de normas que, no seu núcleo, eram atribuídas ao legislador Sólon. Isto era bastante diferente do que iria suceder em Roma, em que a simples oportunidade bastava, para justificar o advento de novas leis.

Havia um genuíno 'processo legislativo; para alterar as leis antigas. E ele era de todo incindivel da concepção de 'lei', como emanação da divindade. Não é demais lembrar que Sólon teve existência histórica. Mas isto não acontece, relativamente a outros legisladores da Hélade, entre os quais, Licurgo. Aliás, a imutabilidade da lei foi uma constante, no que tange a Esparta.

Havia formalidades prescritas, para que novas leis fossem introduzidas em Atenas. E a não-observância de tais formalidades, implicava em sanções. Qualquer cidadão podia intentar uma ação pública, contra o que tivesse obtido a aprovação de uma nova lei, sem observar as formalidades prescritas. Bastava, para intentar a ação pública, que o cidadão considerasse que

6. Vide $O$ Poder na Antiguidade cit., p. 98, itálico no original. 
as formalidades não haviam sido seguidas. Era suficiente o seu parecer, enquanto cidadão de Atenas. A ação pública, em epígrafe, tinha o nome de graphé paranómon. Uma outra observação a ser feita é a de que no decurso da ação pública, eram discutidas a legalidade do procedimento, e a oportunidade da lei aprovada. É digno de nota, pois, que o procedimento ora examinado não se ocupava, apenas, dos aspectos : formais da nomogênese: por meio dele, também o mérito da lei nova era examinado" 7

Tudo indica que o procedimento conhecido no Direito ático, sob o nome de "graphé paranómon" seja o mais remoto ancestral daquilo que, hoje, recebe o "nomen juris" de "controle de constitucionalidade" Ao tratarmos do Direito Público da Hélade, não podemos prescindir da consulta ao livro clássico de Gustave Glotz, intitulado A Cidade Grega. Escreve o autor, verbis:

"Para determinar com precisão o poder legislativo da Ekklêsía, há necessidade de esclarecer o sentido exato das palavras nómos (lei) e psêphisma (decreto). Não é numa época como a nossa, em que os mais sábios juristas de todos os países sentem uma dificuldade singular em definir esses dois termos - e em que a democracia francesa chegou mesmo a introduzir na fraseologia política o termo híbrido 'decreto-lei' -, que nos assiste o direito de lançar a primeira pedra na democracia ateniense por ter deixado vaga a diferença existente entre dois conceitos que, no entanto, são essenciais.

Em todo o caso, o direito público de Atenas proclamava, em princípio, que nenhum decreto, nem do Conselho nem do povo, prevalece contra a lei

7. Op. cit., pp. 98 e 99 - itálico no original. 
(psêphisma mêdèn, mête boulês mête dêmou, nómou kuriôteron eînaí)" 8

Anota Glotz que, no século V a.C., os atenienses entendiam por "leis" todas as leis, e, sobretudo, as leis constitucionais de Drácon, Sólon e Clístenes. ${ }^{9}$ Importa aqui salientar que, de acordo com o autor de $A$ Cidade Grega, a graphé paranómon" era uma instituição judiciária destinada a conter, na prática, a onipotência da Ekklêsía dentro de "justos limites" Tratava-se de uma ação pública contra moções legais. Observa Glotz, verbis.

De fato, essa ação era, pelas suas origens, pelo seu rito processual e pelas suas sanções, uma das mais temíveis armas de que dispunha o direito penal em Atenas." $^{10}$

De acordo com o autor ora seguido, a "graphé paranómon" teria surgido após a reforma de Efialtes, que despojou o vetusto Tribunal do Areópago do papel de guardião da Constituição. Cumpre salientar que todo e qualquer cidadão podia se apresentar como protetor das leis, para processar o autor de uma proposta ilegal, e até mesmo o presidente da assembléia, que não se havia recusado a colocála em votação. Vamos dar a palavra a Gustave Glotz. Escreve ele, verbis.

" $O$ acusador devia formular a sua queixa por escrito, indicando a lei que, a seu ver, fora violada. Podia anunciar a sua intenção sob juramento (hupômosía), na Assembléia do povo, antes ou depois de votadas as disposições que ele julgava ilegais. Essa declaração oficial tinha o efeito de suspender a validade do decreto até depois de pronunciada a sentença. O tribunal,

8. Vide Op. cit., tradução brasileira de Henrique de Araújo Mesquita e Roberto Cortes de Lacerda, Rio de Janeiro, Editora Bertrand Brasil S.A., $2^{2}$ ed., 1988, p. 136 - itálico no original - original francès.

9. Op. e loc. cit.

10. Op. cit., p. 147. 
composto no mínimo de mil jurados e, algumas vezes, de seis mil, funcionava sob a presidência dos thesmothétai. Qualquer proposta podia ser atacada sob a alegação de conter vício em sua forma: era suficiente que não se tivessem observado as regras severas do processo. Um decreto era ilegal se tivesse sido submetido à Assembléia sem haver sido previamente examinado e relatado pelo Conselho ou sem ter sido incluído na ordem do dia pelos prítanes. Uma lei era ilegal se não tivesse sido proposta como resultado de uma votação expressa na primeira assembléia do ano, e se não houvesse sido afixada em tempo hábil e no devido lugar. Ainda mais séria, como é natural, era a ilegalidade que se prendia não à forma, mas ao fundo" 11

Havia - prossegue o autor - punições severas para a ilegalidade. Tais punições iam das multas razoavelmente pesadas, até a pena de morte. Depois de três condenações por ilegalidade, o cidadão perdia o direito de apresentar quaisquer propostas à Assembléia do "Demos" Numa observação pessoal, lembramos aqui que esta era uma punição deveras pesada, uma vez que os valores fundantes da Democracia ateniense eram a "isonomia" ou seja, o privilégio de obediência às mesmas leis, e a "isegoria" ou seja, o direito de fazer uso da palavra, nas assembléias...como, com argúcia, observa o insigne Miguel Reale in Horizontes do Direito e da História. A "igualdade" era mais importante, na Democracia de Atenas, do que a "liberdade... " 12 Conclui Glotz:

"Finalmente, sujeitando-se à graphê paranómôn, a democracia ateniense estava pronta para colher a sua mais bela recompensa: tornava infrutifera qualquer tentativa de prejudicar a constituição através das vias

\footnotetext{
11. Op. cit., pp. 147 e 148 - itálico no original.

12. Op. cit., p. 28.
} 
constitucionais e não deixava ao partido oligárquico outra alternativa além da revolução" 13

Os consagrados autores patrícios José Pedro Galvão de Sousa, Clovis Lema Garcia e José Fraga Teixeira de Carvalho também vislumbram, no instituto ateniense ora estudado, o embrião do hodierno controle de constitucionalidade, porquanto ensinam, verbis:

"No século $V$ a.C., já se entremostra em Atenas a idéia da atual argüição de inconstitucionalidade de lei (graphé paranomos), para manter intangível a constituição" 14

Não é possível ignorar que, se Sólon foi o "pai" da Democracia ateniense, o instituto ora em estudo, que punha um freio aos desmandos da Assembléia do "Demos" foi a manifestação jurídica dos conceitos de "medida" e de "limite" presentes no pensamento do legendário legislador. Di-lo Werner Jaeger, com a sua habitual clarividência:

" O conceito de medida e de limite, que ganhará importância tão fundamental na ética grega, revela claramente qual é o problema que se situa no centro do pensamento de Sólon e do seu tempo: a aquisição de uma nova forma de viver, por meio da força do conhecimento interior" ${ }^{15}$

13. Op. cit., p. 149.

14. Vide Dicionário de Política, São Paulo, T. A. Queiroz, Editor, 1998, p. 134 itálico no original.

15. Vide Paidéia - A Formação do Homem Grego, tradução portuguesa de Artur M. Parreira, São Paulo, Livraria Martins Fontes Editora Lida. - Editora Universidade de Brasilia, 1986, p. 129 - original alemão. 
Mauro Cappelletti é um outro autor que vislumbra, no Direito ático, o remoto ancestral do nosso atual controle de constitucionalidade, escrevendo a propósito:

A conseqüência da ilegalidade (ou, como nós gostaríamos de dizer, da inconstitucionalidade) dos decretos emanados da Ecclesía era dúplice. Por um lado, dela derivava uma responsabilidade penal para aquele que havia proposto o decreto, responsabilidade que se podia fazer valer dentro de um ano, mediante uma ação pública de ilegalidade, chamada grafê paranómon. Por outro lado, julga-se que derivasse, ainda, a invalidade do decreto contrário à lei, por força do principio que se encontra afirmado em um trecho de Demóstenes, segundo o qual o nómos, quando estava em contraste com um pséfisma, prevalecia sobre este. Os juízes atenienses, portanto, não obstante fossem obrigados por solene juramento a julgar 'Kata toùs nómous Kaí Katá psefísmata' ('segundo a lei e segundo os decretos'), não podiam, porém, ser obrigados a julgar segundo os psefismata, a menos que estes não fossem contrários aos nómoi" ${ }^{16}$

Verificamos, destarte, que o instituto ora estudado, ao que tudo indica, deita as suas raízes no Direito Público da Hélade, e, de maneira mais específica, na Constituição de Atenas.

II Roma: - o pensamento de Marco Tulio Cícero

Como já assinalamos retro, a vocação nacional dos romanos foi o Direito. E, na abordagem do tema de que ora nos ocupamos, têm grande importância

16. Vide O Controle Judicial de Constitucionalidade das Leis no Direito Comparado, tradução brasileira de Aroldo Plínio Gonçalves, Porto Alegre, Sergio Antonio Fabris Editor, 2ª ed., 1992, pp. 50 e 51, itálico no original - original italiano. 
os estudos feitos, pelos romanos, a propósito do Direito Natural. Um nome se impõe aos que abordam, em Roma, o Direito Natural. É o de Marco Tulio Cícero, sobre o qual escreve Eustaquio Galán y Gutierrez, verbis:

"La figura que de veras tiene relevancia, desde el punto de vista de nuestra disciplina, es Cicerón (106 43 a. de J.C.), personalidad multifacética (abogado, retórico, político y artista de la pluma). De importancia directa para el derecho natural son tanto el tratado De legibus (probablemente dejado sin teminar por el autor), cuanto el tratado De republica, obra de la que sólo ha Ihegado a nosotros la tercera parte, aproximadamente, descubierta por May en 1822, en un palimpsesto de la biblioteca vaticana. Desde el punto de vista de la filosofia moral también son relevantes los tratados De oficiis, De finibus bonorum et malorum, los Tusculanarum disputationum libri quinque" 17

Como é amplamente sabido, afirma o autor espanhol citado, as obras de Cícero estão prenhes de elementos platônicos, aristotélicos e estóicos. Todos os seus escritos se alimentam de idéias gregas. De acordo com o genial orador das Catilinárias, o genuino saber respeitante ao Direito tem que ser buscado não no Edito do Pretor (non a praetoris edicto), nem na Lei das XII Tábuas (neque a XII tabulis), porém, na mais íntima entranha da Filosofia (sed penitus ex intima philosophia). E isto porquanto o que inquieta Cícero - sempre de acordo com Eustaquio Galán y Gutierrez - é o problema da "fons ultima juris". 18

A verdadeira lei, de acordo com Cícero, é a razão, cujo fundamento se acha na natureza, na medida em que prescreve o que se deve fazer, e proíbe o contrário (lex est ratio summa, insita in natura, quae iubet ea quae facienda sunt, prohibet contraria). ${ }^{19} \mathrm{~A}$ verdadeira lei - diz Cícero - não é uma arbitrária invenção

17. Vide Ius Naturae, Madrid, Sucesores de Rivadeneyra, S.A., 1961, v. II, pp. 60 e 61 - ilálico no original.

18. Op., vol. e loc. cit.

19. Op. e vol. cit., p. 62 . 
do engenho humano, nem um mandamento feito pelos povos, porém algo eterno que rege o mundo, e que impera ou próbe. Afirma ainda o famoso retórico que a verdadeira lei é um critério para a distinção do justo e do injusto, ditado pela natureza. O verdadeiro princípio constitutivo do Direito radica em uma lei fundamental, válida para todos os tempos, estabelecida antes que qualquer lei escrita tivesse sido ditada, e antes, inclusive, que qualquer cidade tivesse sido organizada. ${ }^{20}$ Um pensamento ciceroniano que - observa o autor ora seguido - se repete reiteradamente no De Legibus é o de que o genuíno Direito é estabelecido pela natureza (jus in natura esse positum intellegi possit), e que, da mesma forma que o Direito encontra o seu fundamento na natureza, o verdadeiro critério para distinguir a lei justa da injusta não pode consistir senão em consultar a natureza. ${ }^{21}$

Não podemos deixar de consignar que as idéias respeitantes ao Direito Natural, trabalhadas por Cícero, integravam a cultura helênica, estando presentes naquela manifestação do espírito que, entre os gregos, teve maior importância do que em qualquer outro povo: o teatro. Com efeito, em Sófocles, ao ser interpelada por Creonte, a respeito de ter $o$ atrevimento de desobedecer às leis, responde Antígona:

Mas Zeus não foi o arauto delas para mim, nem essas leis são as ditadas entre os homens pela Justiça, companheira de morada dos deuses infernais; e não me pareceu que tuas determinações tivessem força para impor aos mortais até a obrigação de transgredir normas divinas, não escritas, inevitáveis; não é de hoje, não é de ontem, é desde os tempos mais remotos que elas vigem, sem que ninguém possa dizer quando surgiram" 22

A propósito da influência do pensamento helênico no Direito Romano, e, mais especificamente, a propósito do surgimento de uma "Filosofia do Direito" em Roma, escreve Roscoe Pound:

20. Op., vol. e loc. cit.

21. Op. e vol. cit., p. 63.

22. Vide $A$ Trilogia Tebana, tradução de Mario da Gama Kury, Rio de Janeiro, Jorge Zahar Editor, $2^{a}$ ed., 1991, p. 214 - grifos nossos - original grego. 
A lei de Atenas, nos séculos IV e $V$ a.C., era uma tradição codificada, cujas deficiências eram supridas por legislação apropriada e individualizada em sua aplicação, mediante a administração de justiça por vastas assembléias populares. Dessa maneira, apesar da redução formal à escrita, a lei ateniense conservou a fluidez do Direito primitivo e pôde propiciar uma Filosofia para a lei romana, em sua fase de equidade $e$ direito natural - outro período de fluidez legal" 23

Mais adiante, preleciona o autor norte-americano, verbis:

"Os homens de lei romanos entraram em contato com a Filosofia na transição entre uma lei escrita e uma fase de eqüidade e direito natural. Esse contato influiu bastante, ao habilitá-los a concretizarem a mencionada transição. De um ponto de vista puramente legal, o Direito grego estava numa fase de lei primitiva. Direito e Moral estavam ainda, em grande parte, indiferenciados. Assim, o pensamento filosófico grego de uma fase de Direito e Moral indiferenciados permitiu a identificação do que era legal com o que era moral, no pensamento jurídico que caracterizava o Direito Romano clássico" ${ }^{24}$

Embora - no dizer feliz de Alexandre Augusto de Castro Corrêa - o contributo da Filosofia Grega tenha chegado para os jurisconsultos romanos em um momento em que o Direito Romano já havia atingido a sua maioridade científica; e embora os romanos tenham chegado - graças à influência helênica - à concepção do Direito Natural, seria temerário afirmar que os limites impostos pelo Jus Naturale.

23. Vide Introdução à Filosofia do Direito, tradução brasileira de Álvaro Cabral, Rio de Janeiro, Zahar Editores, 1965, p. 16 - original norte-americano.

24. Op. cit., pp. 18 e 19. 
constituíssem, por si mesmos, no Direito Romano, aquilo a que chamaríamos, hoje, de "controle da constitucionalidade" Tais limites poderiam, isto sim, servir de referencial para o exercício do mencionado controle. Este era, a rigor, exercido pelo Senado, escrevendo a respeito José Pedro Galvão de Sousa; Clovis Lema Garcia e José Fraga Teixeira de Carvalho:

"Também em Roma, atuava o Senado como legis iudex, ao cassar leis contrárias à ordem institucional. E transcendendo a ordem jurídico-positiva, Cícero (106 43 a.C.), no Senado, ao invocar a recta ratio contra a lex scripta, arguia a invalidade da norma atentatória à lei natural, ou seja, uma como que inconstitucionalidade per se, em razão da afronta do direito positivo ao direito natural. Por isso, autores há, como Corwin, que afirmam ter Cícero contribuído indiretamente, com essas idéias, para a futura formulação do judicial review (The 'Higher Law' Background of American Constitutional Law, Cornell University Press, New York, 1961, p. 14)" 25

III A Idade Média. Jus Naturale e Jus Positum

De acordo com Mauro Cappelletti, as concepções pertinentes ao Direito e à Justiça dominantes no Medievo estavam ligadas - em sentido muitíssimo amplo - ao pensamento de Platão e de Aristóteles. Mas estavam elas ligadas, também, e em especial por meio da doutrina tomista, aos filósofos estóicos e a Cícero. ${ }^{26}$ Como é evidente, em tais concepções medievais a idéia de um Jus Naturale" assumia um papel de inquestionável preeminência. Como escreve M. Battaglini, "o ato soberano que tivesse infringido os limites postos pelo direito natural era declarado formalmente nulo e não vinculatório, tanto que o juiz competente para aplicar o direito era obrigado a considerar nulo (e por isto não

25. Op. e loc. cit.

26. Op. cit., p. 51. 
obrigatório) seja o ato administrativo contrário ao direito (natural), seja a própria lei que se encontrasse em semelhante condição, mesmo que ela tivesse sido proclamada pelo Papa ou pelo Imperador. Segundo, enfim, alguns teóricos, mesmo os súditos individualmente considerados estavam desobrigados do dever de obediência em face do comando não conforme ao direito (natural), tanto que a imposição coativa da norma antijurídica justificava a resistência, mesmo armada e, até, o tiranicídio" 27

Se o "Jus Naturale" teve tamanho relevo na Idade Média, cremos ser de bom alvitre trazer à baila algumas definições dele. Fixamo-nos em dois autores, Don Faustino Gutiérrez Alviz e Raymond Monier. Escreve o primeiro, verbis:

"Ius Naturale. - Derecho natural. Una primera acepción supone que es, conforme com el sentir del jurista Ulpiano, 'el que la Naturaleza enseña a todos los animales; cual las normas que rigen al hombre y las bestias relativas a la unión de los dos sexos, procreación y cuidado de la prole; concepto non admisible desde el punto de vista jurídico. Otra acepción es la de Paulo, quien le estima como 'lo que siempre es bueno y justo: concepto de un derecho ideal, que enfrentado por los juristas compiladores al derecho de gentes constituia un derecho raciona (sic), ideal e inmutable. Esta concepción del derecho parece ser obra de los compiladores bizantinos y en modo alguno responde a ideas de los juristas clásicos'. ${ }^{28}$

Raymond Monier, por seu turno, ensina:

J. Naturale (Droit Naturel). - 1) Droit idéal n'ayant pas, par lui-même, force obligatoire, qui est le même chez tous les peuples et dans tous les temps, et qui est la

27. Apud. Mauro Cappelletti, Op. cit., p. 52 - itálico no original.

28. Vide Diccionario de Derecho Romano, Madrid, Instituto Editorial Reus, 1948, p. 297 negrito e maiúsculas no original. 
source à laquelle le législateur e le jurisconsulte doivent puiser pour perfectionner le droit en vigueur à un moment donné, dans un pays déterminé. - 2) D'après certains écrivains grecs et latins, dont l'opinion est suivie par Justinien: droit commun à l'homme et à tous les animaux, que la nature enseigne à tous les êtres animés et qui comprend l'union du mâle et de la femelle, la procréation et l'education des enfants'" 29

$\mathrm{Na}$ abordagem do controle de constitucionalidade na Idade Média, não podemos olvidar um dado, fundamental, sobre esta época da História da Humanidade: ela foi eminentemente Teocêntrica, dai derivando a enorme importância da Igreja Católica, para a evolução das instituições jurídicas aí incluídas. Nesta ordem de idéias, assinala o já citado professor José Pedro Galvão de Sousa que os escolásticos, inspirando-se imediatamente no Decretum de Graciano, e mediatamente nas lições de Santo Isidoro de Sevilha, ensinavam ser a lei natural a participação da lei eterna no homem. ${ }^{30}$

Como é sabido, existem diversas vertentes do chamado Direito Natural. Isto inobstante, parece ser possível a sua redução a um denominador comum, escrevendo a propósito José Pedro Galvão de Sousa, verbis:

"Enfim, das fontes greco-romanas, aproveitadas na Idade Média, pelos canonistas e teólogos, resultou toda uma tradição doutrinária sobre a lei natural. Não obstante as multíplices variantes dessa tradição, é unânime a aceitação de um princípio superior de conduta, regra geral de toda ação humana, inerente à própria natureza e critério supremo da justiça e da equidade. Baseado na distinção entre o bem e o mal, o justo e o injusto, esse princípio é universalmente

\footnotetext{
29. Vide Vocabulaire de Droit Romain, Paris, Éditions Domat Montchrestien, quatrième édition, 1948, p. 164 - negrito e maiúsculas no original.

30. Vide Direito Natural, Direito Positivo e Estado de Direito, Sāo Paulo, Editora Revista Dos Tribunais, 1977, pp. 5 e 6.
} 
admitido, porque evidente, e assim pode formular-se: devemos praticar o bem e evitar o mal. É o direito natural, de que dizia Paulo: quod semper aequum ac bonum est, ius dicitur, ut est ius naturale. 31

Como vimos há pouco, a Idade Média foi eminentemente teocêntrica, sendo este dado fundamental para que bem a compreendamos. Cremos ser interessante, neste passo, ilustrar a assertiva, trazendo à baila o autor que tão profundamente marcou o pensamento filosófico, jurídico e político do Medievo Europeu: Santo Tomás de Aquino. Ao dar conselhos ao governante, escreve o doutor Angélico:

"Já que tamanha recompensa se aparelha, na beatitude celeste, aos reis que bem governarem, devem êles, com cuidado diligente, ter mão em si-mesmos, para se não perverterem à tirania. Que nada lhes deve ser mais grato que, da régia honra com que são sublimados na terra, serem transferidos à glória do reino celestial. Erram, porcerto, os tiranos, que, por-causa de certos interêsses terrenos, abandonam a justiça e se privam do tão grande prêmio que podiam alcançar reinando justamente" 32

De acordo com Mauro Cappelletti, em termos de Idade Média, e em função da já aludida - e inescondível - preeminência do "Jus Naturale" houve uma tendência no sentido de substituir a fórmula romana (ou pseudo-romana) "Princeps legibus solutus" pela fórmula oposta Princeps legibus tenetur" Houve ainda, sempre de acordo com o autor peninsular, a elaboração de uma tese intermediária, de acordo com a qual o soberano, não vinculado à lei civil, estava, entretanto, vinculado à lei natural. ${ }^{33} \mathrm{Em}$ consonância com a concepção medieval, pois, havia uma

31. Op. e loc. cit. - itálico no original.

32. Vide Do Govêrno dos Príncipes, tradução e anotações do professor Arlindo Veiga dos Santos, São Paulo, Editora Anchieta S/A, 1946, p. 73.

33. Op. e loc. cit. 
distinção nítida entre as duas ordens de normas, a do Jus Naturale" "norma superior e inderrogável" e a do "Jus Positum" obrigada a não estar em contraste com a anterior. ${ }^{34}$ Com as indispensáveis cautelas pertinentes às particularidades da época histórica abordada, vamos concluir dizendo que a adequação ou a inadequação das normas do Jus Positum" aos preceitos do Jus Naturale". faziam as vezes do que hoje chamamos de "controle de constitucionalidade"

\section{IV - O Jusnaturalismo dos séculos XVII e XVIII}

A existência das duas ordens de normas, a do Jus Naturale" e a do Jus Positum" é válida também, e "grosso modo" para a concepção dominante no que Cappelletti chama de "grande escola jusnaturalista dos séculos XVII e XVIII" 35 Esta escola, segundo o autor italiano, vai de Hugo Grotius a J.J. Rousseau. Dissemos e reiteramos que a Idade Média foi teocêntrica. Pois bem, esta escola Jusnaturalista de que ora nos ocupamos mereceria ser chamada de "antropocêntrica" porquanto desvinculada dos pressupostos teológicos e transcendentes do Direito Natural do Medievo - tinha fundamentos racionalistas e imanentistas. Ocorre que também ela afirmava a existência de "direitos inatos" intangiveis e irrenunciáveis. PPara Cappelletti, tal escola afirmava "a existência de limites e de preceitos cogentes para o próprio legislador" ${ }^{36}$ Esta concepção estava arraigada no pensamento da época. Abraçou-a John Locke, o qual, embora afirmando que o Legislativo detém o "supreme power" admitia que este poder tem que encontrar limites no Direito Natural. Célebre é a frase atribuída a Walter Bagehot: "O Parlamento pode fazer tudo, exceto transformar a mulher em homem ou vice-versa." Inobstante isto, a distinção entre um Direito Natural e um Direito Positivo destinava-se a atuar, como o salienta Cappelletti, "num plano puramente filosófico e teórico, abstraído dos concretos acontecimentos quotidianos da vida" ${ }^{37}$ Em síntese, quando havia a oposição entre as normas de Direito Natural e as do Jus Positum" tratava-se da oposição de normas integrantes de duas ordens jurídicas diversas; da oposição entre dois sistemas jurídicos diversos (grifamos). Escreve o autor peninsular:

34. Op. e loc. cit.

35. Op. e loc. cit.

36. Op. cit., p. 53 - os grifos em maiúsculas e negritos são nossos.

37. Op. e loc. cit. 
"Pelo que, não sei quantas vezes em concreto o juiz, colocado diante do divergente comando da norma, com freqüência muito vaga, de direito 'natural' de um lado, e da norma de direito 'positivo' de outro lado, efetivamente pudesse ou soubesse, sem incorrer em responsabilidade, ou talvez em arbítrio, não aplicar a segunda para aplicar, ao contrário, a primeira' ${ }^{38}$

Para chegar à subsunção do Direito Natural na esfera do Direito Positivo, adverte Mauro Cappelletti, foi necessário que decorresse mais algum tempo. Um primeiro sintoma da mudança pode ser encontrado no Reino de França, já ao tempo do Ancien Régime" Com efeito, os Parlements" - que eram Cortes superiores de Justiça - vinham afirmando, em face dos monarcas franceses, o seu poder e dever "d'examiner dans les édits e autres lois qui nous sont apportés s'il n'y a rien de contraire ... aux lois fondamentales du royaume" ${ }^{39}$ Em nota de rodapé da p. 55, elucida o jurista peninsular que o "Parlement" de Paris, no ano de 1718 , proferiu uma decisão no sentido ora apontado. Os "Parlements" teriam a função de "gardiens des lois fondamentales" Um dado básico para o estudo do nosso tema, e presente, por igual, em uma nota de rodapé da página citada, é o de que, desde o século XVI, estava se desenvolvendo, na França, a teoria das "leges imperii" as quais, embora distintas tanto das leis divinas quanto das leis naturais, como estas, não podiam ser alteradas, nem pelo Rei, nem pelos Estados Gerais (grifamos). Com lastro na obra dos Parlements"- assinala Mauro Cappelletti - foi sendo formulada uma doutrina que teve grande influência sobre a obra de Montesquieu: - a doutrina da "heureuse impuissance" pela qual havia uma "feliz impotência" do soberanolegislador, no sentido de promulgar leis que, hodiernamente, seriam chamadas de "leis inconstitucionais" 40

Desejamos aqui consignar uma observação pessoal. Cremos que o fato de, em pleno Ancien Régime" haver um freio à prepotência e ao arbítrio reais, demonstra à sociedade que as instituições jurídicas e políticas não evoluem de

38. Op. cit., p. 54.

39. Transcrito por Mauro Cappelletti, Op. cit., pp. 54 e 55 - itálico no original.

40. Op. cit., pp. 55 e 56. 
maneira brusca, e que as rupturas consubstanciadas nos períodos revolucionários não constituem inovações tão notáveis quanto aparentam ser, "prima facies"...

V Inglaterra. A luta entre el-Rei e o Parlamento. A "Revolução Gloriosa" e a supremacia do Parlamento

O embrião do Parlamentarismo Britânico deve ser vislumbrado, segundo José Pedro Galvão de Sousa, Clovis Lema Garcia e José Fraga Teixeira de Carvalho, na "Magna Charta Libertatum" outorgada em 1215 por João Sem Terra, Rei de 1199 a $1216 .{ }^{41}$ O monarca, como é sabido, foi pressionado no sentido de respeitar o princípio em que se assentavam as instituições políticas durante o Medievo, vale dizer: o Rei governa "sub lege" isto é, observando as normas jurídicas derivadas da ordem natural das coisas e das "leis fundamentais" Este direito, como é amplamente conhecido, era um Direito Costumeiro. Na época da "Magna Charta" o jurisconsulto Henry Bracton, expoente do Direito Medieval inglês, escreveu, "verbis": Ipse autem rex non debet esse sub homine sed sub Deo et sub lege quia lex facit regem" ou em vernáculo, "o próprio rei não deve estar sob o homem, mas sob Deus e sob a lei, porque a lei faz o rei" ${ }^{42}$

Da "Magna Charta Libertatum" escrevem os autores nacionais ora seguidos:

A Magna Charta Libertatum, que, não obstante a denominação, nenhuma semelhança possui com as constituições modernas, visou assegurar o compromisso real de observância desse princípio, concretizado sob vários aspectos: lançamento de tributos mediante audiência prévia dos contribuintes, respeito às prerrogativas municipais, liberdade da Igreja, obediência às normas processuais na apuração de delitos' 43

41. Vide o Dicionário de Politica cit., p. 400.

42. Op. e loc. cit.

43. Op. e loc. cit. - itálico no original. 
Há uma tendência, entre os estudiosos atuais, no sentido de assimilar a Magna Charta" às modernas constituições. Nada mais equivocado. Em termos políticos, é preciso salientar que João Sem Terra, a quem os barões e os bispos, literalmente, arrancaram o documento, personificava, naquele momento histórico, aquilo que, à falta de um nome mais adequado, chamaremos de "a modernidade": o monarca era o embrião da vontade do Estado Nacional, a se opor contra os privilégios feudais dos nobres e do alto clero...

Quando da "Magna Charta" o Rei da Inglaterra era assistido pela "Curia Regis" ou Privy Council" em suas decisões mais importantes. Com a ampliação excessiva dos integrantes deste Conselho, formou-se o "Consilium Regis" dotado de funções judiciais, governamentais e legislativas ${ }^{44}$ (grifos nossos). Entre os membros do "Consilium Regis" e o soberano realizavam-se os "colloquia" Tratavase do 'Parliamentum' esboço do futuro Parlamento, que surgiu, finalmente, em 1265, congregando - apenas - os representantes da Nobreza e do Clero. Em 1295, o Parlamento passou a ser integrado pelas três classes sociais: -"Os que rezam, os que guerreiam, os que trabalham" ${ }^{45}$ Data de meados do século XIV a divisão do Parlamento em duas câmaras, a dos Lordes e a dos Comuns, com atribuições que se foram definindo e consolidando.

Após a ditadura de Oliver Cromwell, e restaurada a monarquia, o "Gabinete" integrado por ministros nomeados livremente pelo Rei, tornou-se um instrumento do poder absoluto do monarca. Não devemos esquecer, neste passo, que as doutrinas de Thomas Hobbes serviram para justificar o absolutismo da Casa dos Stuart. Ao escrever sobre este autor, assim se expressa Guido Fassò, verbis:

En realidad, no debe olvidarse que toda su obra surge en el clima de la guerra civil y responde a su toma de posición en favor del absolutismo: la causa primera de la lucha que castigó a Inglaterra, a su juicio, era la división de los poderes del Estado, y no vio otra

44. Op. e loc. cit.

45. Op. e loc. cit. 
perspectiva de paz que el reconocimiento de la inseparabilidad de todos los poderes." ${ }^{46}$

Como é sabido, o absolutismo real praticado por James Stwart levou à "Revolução Gloriosa" de 1688, cujo objetivo era restabelecer o respeito ao princípio "rex sub lege" Com a Revolução de 1688, assinala Cappelletti, passa a haver na Inglaterra a absoluta supremacia do Parlamento. ${ }^{47}$ Sucede que, ao mesmo tempo, ensinam os autores do Dicionário de política, vinha a se consolidar o princípio segundo o qual os atos do Parlamento que atentassem contra a Common Law (Direito Costumeiro) seriam nulos. A norma legislada deixava de prevalecer contra a constituição consuetudinária. ${ }^{48}$

VI A contribuição norte-americana

Ao abordarmos a contribuição do Direito norte-americano para o tema ora em estudo, devemos realçar, num "prius" que os EUA integram a grande família do Direito Comum. A propósito, escreve o nosso insígne professor Haroldo Valladão:

"Os Estados Unidos, que herdaram a Common Law nas antigas Colônias, afinal a consagram no seu direito federal e estadual, seja da União, seja dos diferentes Estados-Membros (vd. Oscar Rabasa, El Derecho Anglo-Americano, Common Law, México, 1944), salvo na parte do direito público, em especial do direito constitucional, dada a adoção ali, segundo já vimos, da

46. Vide Hisloria de la Filosofia del Derecho, tradução espanhola de José F. Lorca Navarrete, Madrid, Ediciones Pirámide S. A., 1.979, v. II, p. 105 - original italiano.

47. Op. cit., p. 53.

48. Op. cit., p. 134. 
Constituição, completa, escrita, rígida, de $1787 \mathrm{com}$ as emendas de 1789" 49

Mauro Cappelletti cita um trabalho de James A. C. Grant, vindo à luz em 1963, o qual contém a tese de que o controle jurisdicional da constitucionalidade das leis, na terminologia de língua inglesa, a "judicial review of legislation" é uma contribuição das Américas para a Ciência Política. De acordo com esta tese, o controle jurisdicional das leis representa uma idéia posta em prática, pela vez primeira, nos EUA, no século XVIII. Dos Estados Unidos tal idéia ter-se-ia espalhado, no decurso da passada centúria, para outros países das Américas, difundindo-se, "a posteriori" em outras partes do mundo. ${ }^{50}$

A tese de Grant tem que ser aceita com alguma cautela. E isto porquanto já nos foi dado verificar que, embora não sob o "nomen juris" de "supremacia da Constituição" sobre as leis ordinárias, existiu no passado, no bojo de outras experiências jurídicas, uma espécie de supremacia de uma dada lei ou de um dado corpo de leis (que, na terminologia moderna, poderíamos chamar de "leis constitucionais" ou "fundamentais") em relação às outras leis (que, na terminologia moderna, chamaríamos de "leis ordinárias"). ${ }^{51}$ Isto inobstante, tal tese é, no dizer de Cappelletti, "substancialmente verdadeira" sem ser, porém, "historicamente, de todo correta" ${ }^{52}$ Damos a palavra ao autor italiano, que preleciona, verbis:

"Verdadeiro é, de fato, que antes de ter sido posto em prática o sistema norte-americano de judicial review (of the constitutionality of legislation), nos outros Estados - e refiro-me, em particular, aos Estados da Europa - nada de semelhante tinha sido criado. A razão disto é, de resto, facilmente compreensivel se se pensa

49. Vide História do Direito Especialmente do Direito Brasileiro, Rio de Janeiro, Livraria Freitas Bastos S. A., $4^{2}$ ed., revista e atualizada, 1980, p. 58 - itálico no original.

50. Vide, de James A. C. Grant, El Control Jurisdiccional de la Constitucionalidad de las Leyes. Una Contribución de las Américas a la Ciencia Política, publicação da "Revista de la Facultad de Derecho de México" 1963, apud. Mauro Cappelletti, Op. cit., p. 46.

51. A propósito, Mauro Cappelletti, Op. cit., pp. 48 e 49

52. Op. cil., p. 46. 
que, precisamente, com a Constituição norte-americana, teve verdadeiramente início a época do 'constitucionalismo', com a concepção da supremacy of the Constitution em relação às leis ordinárias" 53

Aduz Cappelletti que a Constituição norte-americana representou o arquétipo das "constituições rígidas" que não podem ser mudadas ou derrogadas por meio de leis ordinárias, mas, eventualmente, através de procedimentos especiais de revisão constitucional. Dispunha a Constituição federal norte-americana de 1787 em seu art. VI, cláusula $2^{\mathrm{a}}$ que "this Constitution (...) shall be the supreme Law of the Land; and the judges in every State shall be bound thereby (...)" ${ }^{54} \mathrm{O}$ texto acima reproduzido foi fundamental na história do instituto ora estudado. Por um lado, ele fixou o que foi chamado de "a supremacia da Constituição" E, de outra banda, ele impôs o poder e o dever dos juízes de negar aplicação às leis contrárias à Constituição, "in se ipsa" Deve ser salientado, outrossim, que foi nos EUA que, pela primeira vez na história do Direito, um sistema de controle da validade das leis foi confiado aos tribunais, tendo, destarte, um caráter judicial.

A propósito desta matéria, assim se pronuncia Carlos Alberto Lúcio Bittencourt:

A idéia de se atribuir às Côrtes de Justiça a guarda da Constituição encontra, efetivamente, sua primeira manifestação histórica na prática constitucional dos Estados Unidos da América. Foi construída pela jurisprudência da Côrte Suprema, na ausência de preceito expresso na Constituição, tendo sido enunciada, em caráter definitivo, no famoso caso Marbury v. Madison, onde o verdadeiro arquiteto do direito constitucional americano - o juiz Marshall - a

53. Op. e loc. cit.

54. Transcrito por Mauro Cappelletti, Op. cit., p. 47. 
expôs limpidamente, imprimindo-lhe a marca do seu gênio" 55

Sobre a histórica decisão proferida no caso Marbury x Madison, escreve Mauro Cappelletti:

A opção do Chief Justice Marshall, com a proclamação da supremacia da Constituição sobre as outras leis e com o conseqüente poder dos juizes de não aplicar as leis inconstitucionais, certamente representou então, repito, uma grande e importante inovação. E se é verdadeiro que hoje quase todas as Constituições modernas do mundo "ocidental" tendem, já, a afirmar o seu caráter de Constituições rígidas e não mais flexíveis, é também verdadeiro, no entanto, que este movimento, de importância fundamental e de alcance universal, foi efetivamente, iniciado pela Constituição norteamericana de 1787 e pela corajosa jurisprudência que a aplicou. $^{56}$

Cremos ser desnecessário acrescentar qualquer outra consideração, pertinente à importância intrínseca da contribuição norte-americana, para a evolução do controle de constitucionalidade das leis.

VII Direito atual: o sistema "difuso" ou "americano" e o sistema "concentrado" ou "austríaco" do controle judicial da constitucionalidade das leis

De acordo com o magistério de Cappelletti, no que diz respeito ao aspecto "subjetivo" ou "orgânico" podem ser distinguidos, na atualidade, dois grandes tipos de sistemas de controle judicial da legitimidade das leis, a saber, o

55. Vide $O$ Controle Jurisdicional da Constitucionalidade das Leis, Forense, Rio de Janeiro, $2^{a}$ ed., 1968, pp. 12 e 13 - itálico e maiúsculas no original.

56. Op. cit., p. 48. 
sistema "difuso" e o sistema "concentrado" No primeiro, o poder de controle pertence a todos os órgãos judiciários de um determinado ordenamento jurídico, que o exercitam incidentalmente, quando da decisão das causas de sua competência. No sistema "concentrado" ao revés, o poder de controle está nas mãos de um único órgão judiciário. Lembra o autor, outrossim, que há sistemas que podem ser chamados de "mistos" ou "intermediários" Seria "misto" o sistema adotado pelo México e pela Irlanda. ${ }^{57} \mathrm{O}$ sistema "difuso" foi também denominado "americano" uma vez que, como vimos retro, foi ele posto em prática, pela primeira vez, nos EUA. Por seu turno, o sistema "concentrado" também recebe o nome de "austríaco" dado que foi inaugurado pela Constituição austríaca de $1^{\circ}$ de outubro de 1920. Esta Constituição, em função do mês em que foi promulgada, recebeu o nome de Oktoberverfassung, e foi redigida - ensina Mauro Cappelletti - com base em um projeto elaborado pelo corifeu da "Escola Jurídica de Viena" vale dizer, Hans Kelsen.

Ambos os sistemas, o "americano" e o "austríaco" conseguiram se impor, também em época recente, em vários países, demonstrando possuir "uma verdadeiramente notável força de expansão. ${ }^{58}$ O sistema "americano" é encontradiço em muitas das ex-colônias inglesas, como o Canadá, a Austrália e a Índia. A partir da Constituição de 3 de maio de 1947, é ele o adotado, também, pelo Japão. Na Europa, "uma certa analogia" com o sistema "americano" pode ser vista no Direito suíço. Além disto - aduz Cappelletti - no Direito norueguês, desde o fim do século passado, e no Direito dinamarquês, desde as primeiras décadas do século $\mathrm{XX}$, vem se afirmando o poder dos tribunais de controlar a conformidade das leis com a Constituição, com o corolário de não se aplicar no caso concreto uma lei considerada inconstitucional. Este poder, no entanto, nos dois reinos, vem sendo exercitado pelos tribunais com extrema prudência, e muito de raro em raro. Na Suécia também - anota o jurista italiano ora seguido - vislumbra-se, nestes derradeiros anos, a mesma tendência observada para a Noruega e a Dinamarca.

A Alemanha e a Itália são países nos quais impera hoje um sistema "concentrado" de controle de constitucionalidade. Isto inobstante, em ambos estes paises chegou a existir o controle de tipo "americano" Na Alemanha o controle "difuso" existiu à época da Constituição da República de Weimar, logo depois da

57. Op. cit., p. 67.

58. Op. cit., p. 69. 
derrota alemã na I Guerra Mundial. E, na Itália, tal controle "difuso" esteve em vigor nos anos de 1948 a 1956, isto é, da entrada em vigor da Constituição "rígida" ( $1^{\circ} \mathrm{de}$ janeiro de 1948), até o momento em que passou a funcionar a Corte Constitucional. ${ }^{59}$

O sistema "austríaco" ou "concentrado" teve também uma notável difusão, especialmente nos últimos anos. Houve tentativas - efêmeras, é verdade de o adotar, na Tchecoslováquia em 1920, e na República Espanhola, em 1931. Mas ele foi o adotado, de maneira análoga, pela vigente Constituição Italiana, de $1^{\circ}$ de Janeiro de 1948. Ressalte-se que, na Constituição da Itália, o sistema "austríaco" está em vigor desde 1956, quando foi instituída a Corte Constitucional. Adotaram-no, por igual, a Constituição de Bonn (Ex-Alemanha Ocidental) de 23 de maio de 1949, a Constituição da República do Chipre, de 16 de agosto de 1960, a Constituição da República Turca, de 9 de julho de 1961, e, por derradeiro, a Constituição da República Socialista Federativa da Iuguslávia, de 7 de abril de 1963. Esta última foi a única Constituição de um país comunista a introduzir um sistema de controle de constitucionalidade das leis. No plano federal, tal controle estava afeto a uma especial Corte Constitucional Federal, e, no plano regional, a especiais Cortes Constitucionais de cada uma das seis Repúblicas Federadas. ${ }^{60}$ Em verdade, aduz Mauro Cappelletti, também na República Socialista Tchecoslovaca, houve uma tentativa de se instituir um controle do tipo "concentrado" ou "austríaco" feito pela Lei Constitucional n. 143, de 27 de outubro de 1968, a qual atribuiu a uma Corte Constitucional a ser instituída o controle das leis e de outros atos normativos. Esta Corte Constitucional, no entanto, não chegou a ser criada. ${ }^{61}$

VIII O Direito brasileiro sob a égide da Constituição de 1988

Preleciona Anna Cândida da Cunha Ferraz, "verbis":

"O vício de inconstitucionalidade perturba o ordenamento jurídico-constitucional centrado numa Constituição rígida, posicionada como norma de grau

59. Op. cit, pp. 71 e 72 .

60. Op. cil., p. 73.

61. Op. cit., pp. 73 с 74 . 
superior, que funciona como fundamento de validade das normas inferiores.

Por isso os sistemas constitucionais prescrevem providências, processos e meios para, identificado o vício, saná-lo ou expurgá-lo, restabelecendo-se a ordem constitucional.

Neste contexto é que se insere o controle de constitucionalidade, como conjunto de instrumentos predispostos a assegurar a efetiva sanção do vício, ou seja, a efetiva vigência do princípio da superioridade das normas constitucionais" 62

Prossegue a autora, verbis.

"Consiste, pois, o controle de constitucionalidade em verificar a conformidade ou desconformidade, ou averiguar a adequação ou a inadequação do ato jurídico ou da omissão do poder público frente à Constituição, com o objetivo de, se desconforme ou inadequado, sanar o vício" 63

E conclui Anna Cândida da Cunha Ferraz:

Destarte, pressupõe o controle de constitucionalidade a existência de uma Constituição em sentido formal, escrita e rigida, que se dote a si mesma de meios adequados, expressos e implícitos, aptos a

62. Vide Conflito entre Poderes O Poder Congressual de sustar alos normativos do Poder Executivo - São Paulo, Editora Revista dos Tribunais, 1994, p. 192.

63. Op. e loc. cit. 


\section{fazer prevalecer a sua superioridade de Lei Fundamental do ordenamento jurídico e político" ${ }^{64}$}

Ao tratar dos tipos de controle de constitucionalidade, escreve a ilustre professora do Largo de São Francisco, verbis:

- $O$ exercício do controle de constitucionalidade reveste diversas modalidades que, a seu turno, combinam soluçōes variadas conforme se considere $o$ objeto do controle, os órgãos que o exercem, as circunstâncias em que atua, os instrumentos de que se utiliza ou o tempo dentro do qual incide.

Para o que interessa ao exame do tema, basta lembrar a dicotomia 'controle jurisdicional de constitucionalidade' (o judicial review) e 'controle político de constitucionalidade; ditada em razão do órgão incumbido de verificar a inconstitucionalidade $e$ sancioná-la ou corrigi-la, e a classificação binária que toma como critério o momento em que a relação atocontrole se constitui, ou seja, o controle dito preventivo ou a priori e o controle sucessivo, repressivo ou a posteriori" $^{45}$

Para o nosso modesto estudo, apresenta interesse, fundamentalmente, o controle jurisdicional de constitucionalidade. Manoel Gonçalves Ferreira Filho trata desta matéria, com 0 seu habitual brilhantismo. Perfilha o ilustre constitucionalista das Arcadas a origem norte-americana do instituto ${ }^{66}$ Ao abordar os caracteres do controle jurisdicional de constitucionalidade, escreve o autor, verbis:

64. Op. cil., pp. 192 e 193.

65. Op. cit., pp. 193 e 194 - itálico no original. 30.

66. Vide Curso de Direito Constitucional, São Paulo, Ed. Saraiva, 23ª edição, atualizada, 1996, p. 
$E$ É em principio, de caráter difuso o controle judiciário no Brasil. Perante qualquer juiz pode ser levantada a alegação de inconstitucionalidade $e$ qualquer magistrado pode reconhecer essa inconstitucionalidade e em conseqüência deixar de aplicar o ato inquinado. Trata-se, pois, de controle incidental, de efeito inter partes.

Observe-se que, se todo juiz pode reconhecer a inconstitucionalidade, os tribunais só o podem fazer pela maioria absoluta de seus membros (art. 970)" 67

Se, em princípio, na sistemática do nosso Direito Positivo, o controle jurisdicional de constitucionalidade é difuso, logo, de inspiração "americana" há não olvidar que o legislador previu, também, o controle por ação direta, inclusive, da inconstitucionalidade "por omissão" 68 E aqui está, sem dúvida, o controle "concentrado" "ergo" o "austríaco"...

Na vigência da atual Constituição da República Federativa do Brasil, a Emenda n. 3/93 introduziu a ação (direta) declaratória de inconstitucionalidade de lei ou ato normativo federal. A teor do art. 103, $\S 4^{\circ}$ da Lex Magna, esta ação pode ser proposta, apenas, pelo Presidente da República, pela Mesa do Senado Federal, pela Mesa da Câmara dos Deputados, ou pelo Procurador da República. ${ }^{69} \mathrm{O}$ efeito da decretação de inconstitucionalidade pelo Supremo Tribunal Federal, em sede de ação direta de inconstitucionalidade, é imediato, além de operar erga omnes. ${ }^{70}$

\section{Conclusôes Finais}

Fizemos um ligeiro estudo histórico-jurídico pertinente à evolução do controle de constitucionalidade. Pudemos verificar que, se do ponto de vista estritamente técnico-jurídico, este instituto é uma criação do Direito Público norteamericano, não menos verdadeiro é que a história do Direito revela que, desde o

67. Op. cit., p. 34.

68. Op. e loc. cit.

69. Op. cit., p. 35.

70. Op. cit., p. 36 . 
Direito Público da ática, na velha Hélade, houve freios para o legislador. Tais freios continuaram a existir em Roma, e na Europa Medieval. Cremos ser significativo o dado, por nós examinado no corpo da exposição, de que, na França do "Ancien Régime" os "Parlements" criaram a doutrina da heureuse impuissance do monarca, para violar as leis fundamentais.

No que tange ao hodierno Direito brasileiro, cremos poder afirmar que vigora, entre nós, um sistema misto de controle jurisdicional de constitucionalidade.

"Finis Operae, Deo Gratia"

São João da Boa Vista, julho de 1999

Bibliografia

ALVIZ, Faustino Gutiérrez. Diccionario de Derecho Romano Madrid, Instituto Editorial Reus, 1948.

AQUINO, Santo Tomás de. Do Govêrno dos Príncipes tradução e anotações do Professor Arlindo Veiga dos Santos, São Paulo, Editora Anchieta S/A, 1946.

BITTENCOURT, Carlos Alberto Lúcio. $O$ Controle Jurisdicional da Constitucionalidade das leis - Rio de Janeiro, Forense, $2^{\mathrm{a}}$ ed., 1968.

CAPPELlETTI, Mauro. O Controle Judicial de Constitucionalidade das Leis no Direito Comparado tradução brasileira de Aroldo Plínio Gonçalves, Porto Alegre, Sergio Antonio Fabris Editor, $2^{\mathrm{a}}$ ed., 1992 - original italiano.

CORRÊA, Alexandre Augusto de Castro. O Estoicismo no Direito Romano São Paulo, edição do autor, 1950.

FASSÒ, Guido. Historia de la Filosofía del Derecho - tradução espanhola de José F. Lorca Navarrete, Madrid, Ediciones Pirámide S.A., 1979 - 2 volumes original italiano.

FERRAZ, Anna Cândida da Cunha. Conflito entre Poderes O Poder Congressual de sustar atos normativos do Poder Executivo - São Paulo, Editora Revista dos Tribunais, 1994.

FERREIRA FILHO, Manoel Gonçalves. Curso de Direito Constitucional São Paulo, Edição Saraiva, 23ª ed., atualizada, 1996.

FRANCISCI, Pietro de. Sintesis Historica Del Derecho Romano tradução espanhola, Madrid, Editorial Revista de Derecho Privado, 1954 original italiano. 
GLOTZ, Gustave. A Cidade Grega tradução brasileira de Henrique de Araújo Mesquita e Roberto Cortes de Lacerda, Rio de Janeiro, Editora Bertrand Brasil S.A. $2^{\mathrm{a}}$ ed., 1988 - original francês.

GUTIERREZ, Eustaquio Galán Y. Ius Naturae - Madrid, Sucesores de Rivadeneyra S.A., 19612 volumes.

JAEGER, Werner - Paidéia. A Formação do Homem Grego tradução portuguesa de Artur M. Parreira, São Paulo, Livraria Martins Fontes Ltda. Editora Universidade de Brasília, 1986 original alemão.

LIMA FILHO, Acacio Vaz de. O Poder na Antiguidade: Aspectos Históricos e Jurídicos - São Paulo, Icone Editora, 1999.

MONIER, Raymond. Vocabulaire de Droit Romain Paris, Éditions Domat Montchrestien, quatrième édition, 1948.

POUND, Roscoe. Introdução à Filosofia do Direito tradução brasileira de Álvaro Cabral, Rio de Janeiro, Zahar Editores, 1965 original norte-americano.

REALE, Miguel. Horizontes do Direito e da História - São Paulo, Saraiva S.A., Livreiros Editores, $2^{\mathrm{a}}$ ed. revista e aumentada, 1977.

REZENDE Filho, Gabriel José Rodrigues de. Curso de Direito Processual Civil São Paulo, Edição Saraiva, 19523 volumes.

SÓFOCLES. A Trilogia Tebana - tradução brasileira de Mario da Gama Kury, Rio de Janeiro, Jorge Zahar Editor, $2^{\mathrm{a}}$ ed., 1991 original grego.

SOUSA, José Pedro Galvão de. Direito Natural, Direito Positivo e Estado de Direito - São Paulo, Editora Revista Dos Tribunais, 1977.

Editor, 1998.

et alii Dicionário de Política São Paulo, T.A. Queiroz,

VALLADÃO, Haroldo. História do Direito Especialmente do Direito Brasileiro

Rio de Janeiro, Livraria Freitas Bastos S.A., $4^{\mathrm{a}}$ ed., revista e atualizada, 1980. 